\title{
Crop yield trends in relation to temperature indices and a growth model
}

\author{
Henrik Eckersten*, Alois Kornher, Göran Bergkvist, Johannes Forkman, \\ Erik Sindhøj, Bengt Torssell, Per Nyman
}

Department of Crop Production Ecology, Swedish University of Agricultural Sciences (SLU), 75007 Uppsala, Sweden

\begin{abstract}
Annual variability and trends in winter wheat yields were evaluated for relationships to climate in 6 long-term experiments (in total 1915-2005) and regionally in 3 counties (1965-2008) in southern and central Sweden. The annual yield was predicted as function of a climate index and year. Alternative indices were used based on either monthly temperatures or yield predicted by a simple weather-driven crop growth simulation model. The main results were as follows. (1) The yield predictions were better for regions than for the long-term experiments. (2) The time variable accounted for more of the yield trend in regions than in the experiments, and more in southern than in central Sweden. (3) The models based on a simple temperature index were often better yield predictors than the growth model. (4) The relations to winter temperatures became gradually weaker after ca. 1970. (5) The yield relation to simple temperature indices differed between locations, similarly for experimental and regional yields. (6) The strongest influence of climate was estimated by means of the growth model predictions of regional yields in Gotland County. (7) The fraction of regional yield trends (1965-1996; ranging from 57 to $90 \mathrm{~kg} \mathrm{ha}^{-1} \mathrm{yr}^{-1}$ ) that could be attributed to climate was estimated greatest in the Gotland region (27 to $64 \%$ ). For climate change assessments of winter wheat yield in central Sweden, the growth model considering temperature, radiation and water conditions during spring and summer would also need to include processes of overwintering.
\end{abstract}

KEY WORDS: Winter wheat - Climate - Water - Region - Simulation - Long-term experiment · Regression · Prediction · Sweden

Resale or republication not permitted without written consent of the publisher

\section{INTRODUCTION}

Projected climate change in Sweden is expected to affect agricultural crops so that both production potential and required inputs per unit area will increase (cf. Eckersten et al. 2007a, 2008). Adaptation measures, such as increased fertilisation and pest control, will increase the pressure on the environment and should be balanced against the benefit of increased crop yields. Quantification of climate change impacts on crop yield forms a base for assessing the needs for and effects of adaptation measures. Some process-based crop models can potentially predict climate change effects on yield (cf. Torriani et al. 2007); however, due to the lack of data on required inputs and validation, few of these models (cf. Berntsen et al. 2006, Jaggard et al. 2007) have been tested against long-term crop yield observations available for the last century. Instead, simple climate indices have commonly been tested against long-term yield data. Hence, to make climate change impact assessments, we can choose among using models ranging from simple climate indices (cf. Chauhan et al. 2005) of high applicability and known predictability but low generality, to detailed, process-based models (cf. Ritchie \& Otter 1985, Mearns et al. 1992, Olesen et al. 2000, Eckersten et al. 2007b) with potentially high generality and which account better for variability, but with low applicability and unknown or low predictability (cf. discussion by Challinor et al. 2009).

Long-term analysis of crop yield interactions with weather was already a common research topic in the first part of the 20th century; for example, Hallgren 
(1947) quoted more than 100 references, of which 7 were Swedish. These investigations were on the whole applied only to limited areas, and their general applicability over space and time was unknown. Due to current climate change, there is renewed interest in the analysis of long-term records of crop production in relation to climate.

During 1901-1941, the mean annual temperature in-

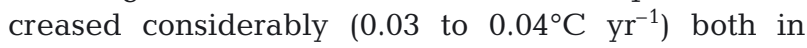
southern (Alnarp, close to Lund) and central (Ultuna, close to Uppsala) Sweden (Hallgren 1947), and the rate was comparable with the current increase rate since 1970 and in projected climate change scenarios for the 2000s (Intergovernmental Panel on Climate Change: www.ipcc.ch). Despite the climate change in the early 1900s, trends in long-term yields of winter wheat from controlled experiments were almost nil in southern Sweden (1890-1917; Wallén 1920) and slightly negative in central Sweden during the first half of the 1900s (1915-1947; Torssell 1953). These observations were made in carefully managed experimental plant breeding plots by the Swedish Seed Association, with constant fertilisation and on the same type of soil year by year. On a regional basis, however, winter wheat yields doubled during the period 1881-1910 in Malmöhus County in southern Sweden, whereas in counties of central Sweden, yield trends over this time period were either nil or very modest (Wallén 1917). During the latter part of the 1900s, trends of increased crop production have been regarded as mostly influenced by technical development, increased nutrient input and plant breeding, among other factors (cf. Ragasits et al. 2000). Based on these historical relations, the technical factor is assumed to dominate over the climate change effect in scenarios of future crop yields (cf. Ewert et al. 2005). However, there are indications during the last decades that these historical trends are not easily generalisable (cf. Peltonen-Sainio et al. 2009a).

Correlations between regional yields and monthly means (or sums) of temperature and precipitation for winter wheat during 1881-1910 in all Swedish counties revealed a varied picture (Wallén 1917, 1920). Among 3 counties, the largest range in the correlation coefficient ( $\mathrm{r}$ ) was found for Gotland (an island in the Baltic Sea +0.70 to -0.55 ), being positive from August to March and most positive for January. In summer, $r$ was negative and most negative for June. In Uppsala, central Sweden, $\mathrm{r}$ was lower but more often positive and most positive for February (+0.50). In Malmöhus County, southern Sweden, the correlations were lower (r ranged from +0.25 to -0.35 ). Positive correlations to winter temperatures (January-April) were also found for the following period, 25-50 yr before 1942 (Hallgren 1947; cf. Arrhenius 1926). Response of winter wheat yield to weather factors differed between vari- eties, and the high-yielding varieties showed high inter-annual variation; however, differences among crops were greater (Torssell 1953).

In attempts to include weather variables other than temperature and precipitation in the regression models, January snow depth, June solar radiation and August temperature accounted for $62 \%$ of the inter-annual variance in winter wheat yield for a $30 \mathrm{yr}$ observation series in Finland (Hollins et al. 2004). In Denmark, there was a positive effect of higher temperature in October, November and January, a positive effect of radiation in April and a negative effect of increased precipitation in July, and the effects of radiation and precipitation were comparably large (Olesen et al. 2000). Earlier studies have thus indicated large differences in simple climate indices to yield relationships between regions and crops and some differences among varieties.

The purpose of this work was: (1) to evaluate the predictability of winter wheat yield over time using simple climate indices (including a simple crop growth simulation model), and (2) to compare the climate relations to yield of long-term experiments with those of regional commercial production.

\section{MATERIALS AND METHODS}

We compared applications of simple temperature indices with simulations of a simple growth model in 3 different climate and agricultural regions of Sweden. We did not consider varietal differences because we prioritised evaluations over long periods, during which varieties changed. Furthermore, we focused only on winter wheat in crop rotation experiments where it is grown with the same preceding crop in all years. We made the analyses for both long-term experiments, which are strongly influenced by local conditions, and regional yields, which represent averages of a large spectrum of local conditions and include influences of the agricultural market and policies (cf. Bakker et al. 2005). By comparing data from different periods, we revealed a base for speculation of shifts in importance of weather-dependent processes influencing winter wheat yield in Sweden. There is also a possible link between variations over time and space, as climate differs within Sweden and has changed systematically during the studied periods. In an analysis of the spatial differences and yield trends in wheat in southern and central Europe, Bakker et al. (2005) pointed out the risk of confounding effects. They found strong relations to climatic, soil and economic variables, and that their relative influences on yield overlapped. In our study, we evaluated the relative effects of climate and time on yield through multivariate regressions with climate index and year as explanatory variables. 
Climatic indices were tested for their relations to yield variations in long-term agronomic trials and regional statistics. The software used for a flexible development and application of the different models was programmed in Matlab/Simulink (MathWork 2005; see also Eckersten et al. 2001).

\subsection{Yield data}

Data from rain-fed long-term agronomic field trials at Ultuna and Säby near Uppsala in central Sweden, Stenstugu near Visby on the island of Gotland, and Borgeby near Lund in southern Sweden were used in the model applications. The soil at Ultuna contained the most clay, and the soil at Stenstugu contained the least clay. The content of organic matter was lowest in Stenstugu and Borgeby, and the sand content was highest in Stenstugu (Table 1).

Yield data of winter wheat were selected from the experiments for categories with the same crop rotation, fertilisation and preceding crop. A selection of variety was omitted, as it almost always resulted in too short periods for a model test. The selection was in some cases also limited by incomplete weather data (Table A1 in Appendix 1). However, different crop rotations were found not to have had significant influence on the yield relation to climate, and on the trends, as evaluated by preliminary tests (data not shown), and were not further addressed, although they are given in Table A1.

Further, regional winter wheat yield of 3 counties were studied. In comparison to the other regions, Uppsala County (central Sweden) had a fairly dry summer climate and predominantly postglacial sorted clay soils. Gotland County (island in the central Baltic Sea) had sunny and dry summers and fertile till soils on calcareous bedrocks, and Malmöhus County (southern Sweden) had a warm and humid climate and fertile till soils (cf. Eriksson et al. 1997). Yield data were taken from the national survey of commercial cultivations (Statistiska centralbyrån [Statistics Sweden]: www.scb.se; cf. Torssell et al. 1986) and represent average yields of the whole region (Table 2). The analyses ended in 1996 because the statistics of Malmöhus thereafter merged into that of a larger region. The area cultivated with winter wheat significantly increased in Malmöhus County but decreased in Gotland. In Uppsala County, the variation between years was high and the trend was not significant from 1965 to 1996; however, thereafter there was an increasing trend (Table 2).

\subsection{Climate index models}

Climate indices $\left(X_{i}\right)$ were derived for different functions of weather variables (Table 3). Two contrasting indices were applied: one quite simple based on 'monthly' temperature sums (no base temperature), and one more complex taken equal to the simulated yield by a growth model accounting for variations in temperature, solar radiation, water availability and plant biomass development (Table 3). The 'monthly' temperature sums from January until 28 August were estimated for $30 \mathrm{~d}$ periods starting from 1 January. The sums of the rest of the year were estimated for $30 \mathrm{~d}$ periods starting from 31 December and going backwards.

The growth model (FOPROQ) was originally developed for leys (cf. Angus et al. 1980, Torssell \& Kornher 1983, Torssell 1989, Fagerberg \& Torssell 1995) but later developed to predict ley and maize yield in practical farming in Germany (Herrmann et al. 2005a,b). The daily growth $(\mathrm{d} W / \mathrm{d} t)$ of aboveground biomass $(W)$ is basically proportional to the maximum relative shoot growth rate $\left(R_{\mathrm{s}}\right)$, but reduced by an age factor $(A G E)$ and a weather-dependent index $(G I)$ :

$$
\mathrm{d} W_{t} / \mathrm{d} t=W_{t-1} R_{\mathrm{s}} A G E_{t-1} G I_{t}
$$

Table 1. Experimental sites used for comparison with climatetime models

\begin{tabular}{|c|c|c|c|}
\hline Site & Coordinates & Soil type & Climate \\
\hline Ultuna & $59^{\circ} 49^{\prime} \mathrm{N}_{;} 17^{\circ} 40^{\prime} \mathrm{E}$ & Clay loam & Uppsala \\
\hline Säby & $59^{\circ} 49^{\prime} \mathrm{N}_{;} 17^{\circ} 42^{\prime} \mathrm{E}$ & $\begin{array}{l}\text { Silty loam (top), } \\
\text { silty clay loam } \\
\text { (deep soil) }^{\mathrm{a}}\end{array}$ & Uppsala \\
\hline Stenstugu & $57^{\circ} 36^{\prime} \mathrm{N}_{i} 18^{\circ} 26^{\prime} \mathrm{E}$ & $\begin{array}{l}\text { Loam (top), } \\
\text { clay loam } \\
\text { (deep soil) }^{\mathrm{a}, \mathrm{b}, \mathrm{c}, \mathrm{d}}\end{array}$ & Visby \\
\hline 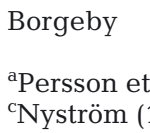 & $\begin{array}{l}55^{\circ} 44^{\prime} \mathrm{N}_{i} 13^{\circ} 04^{\prime} \mathrm{E} \\
\text { t al. }(2008) ;{ }^{\mathrm{b}} \text { Anderss } \\
(1974)_{i}{ }^{\mathrm{d}} \text { Deep soil is }\end{array}$ & $\begin{array}{l}\text { Sandy loamc } \\
\text { n \& Wallgren (19 } \\
\text { ose to sandy clay }\end{array}$ & $\begin{array}{l}\text { Lund } \\
\text { 991); } \\
\text { loam }\end{array}$ \\
\hline
\end{tabular}

Table 2. Winter wheat regional data during 1965-1996. $Y_{\text {Mean: average yield }}$ $\left(\mathrm{kg} \mathrm{ha}^{-1} \mathrm{yr}^{-1}\right) ; A_{\text {Mean }} A_{\mathrm{Max}}$ and $A_{\text {Min }}$ : mean, maximum and minimum area cultivated, respectively (kha); $\mathrm{CV}_{A}$ : coefficient of variation (\%) in year means of area cultivated. The trend in cultivation area is expressed in relation to the average area during the period $\left(\% \mathrm{yr}^{-1}\right) \cdot \mathrm{R}^{2}{ }_{\text {Adj }}$ : adjusted coefficient of determination (\%) of the trend regression. ${ }^{*} \mathrm{p}<0.05$

\begin{tabular}{|c|c|c|c|c|c|c|c|}
\hline County (Climate) & $Y_{\text {Mean }}$ & $A_{\text {Mean }}$ & $A_{\mathrm{Max}}$ & $A_{\text {Min }}$ & $\mathrm{CV}_{\mathrm{A}}$ & Trend & $\mathrm{R}^{2}{ }_{\text {Adj }}$ \\
\hline Uppsala (Uppsala) & 4657 & 16.6 & 34.4 & 0.9 & 48 & $-0.61^{\mathrm{a}}$ & $-2^{\mathrm{a}}$ \\
\hline Gotland (Visby) & 4000 & 7.5 & 10.2 & 1.4 & 24 & $-1.62 * b$ & $39^{b}$ \\
\hline Malmöhus (Lund) & 5778 & 43.7 & 56.4 & 31.4 & 12 & $0.84^{*}$ & 39 \\
\hline \multicolumn{8}{|c|}{$\begin{array}{l}{ }^{\mathrm{a}} \text { For } 1997-2008 \text {, the trend was } 4.62^{*}, \mathrm{R}^{2}{ }_{\text {Adj }}=33 \\
\text { bFor } 1997-2008 \text {, the trend was }-1.47^{*}, \mathrm{R}^{2}\end{array}$} \\
\hline
\end{tabular}


Table 3. Tested climate indices. $T$ : daily mean air temperature

\begin{tabular}{|lll|}
\hline$X_{i}$ & Model & Description \\
\hline$X_{T j}(j=$ Jan, $\ldots$, Dec $)$ & $\Sigma\left(T_{j}\right)(j=$ January, $\ldots$ or December $)$ & Single month $T$ \\
$X_{T \text { Feb+March }}$ & $\Sigma\left(T_{\mathrm{Feb}}\right)+\Sigma\left(T_{\mathrm{Mar}}\right)$ & Periodical $T$ \\
$X_{\text {GrowthModel }}$ & FOPROQ & Growth model \\
\hline
\end{tabular}

where $t$ denotes time given in days. AGE $(=1 /(1+$ $\left.W_{t-1} / a_{\text {Age }}\right)^{b \text { Age }}$ ) reflects the influence of plant development and senescence, where $a_{\text {Age }}\left(\mathrm{g} \mathrm{m}^{-2}\right)$ and $b_{\text {Age }}$ (dimensionless) are parameters. GI is the product of indices for temperature, incident solar radiation and the soil water availability, respectively. The water availability equals the difference between accumulated precipitation and evapotranspiration plus the initial soil water content (see Herrmann et al. 2005a). The model includes fewer functions than more detailed simulation models predicting winter wheat yield (e.g. Weir et al. 1984) basically simulating light interception, net carbon dioxide assimilation, transpiration, nitrogen uptake, partitioning of biomass and nitrogen among leaf, straw, root and grain, leaf area and root depth development, maintenance respiration and development stages modifying the rates of many of these processes. This type of model was regarded as not applicable here due to the many parameters and few data. The FOPROQ model considers only a few main parts of the more detailed winter wheat models. Autumn and winter growth was not simulated, as the simulation started in spring. The relative growth rate $\left(W \times R_{\mathrm{s}}\right)$ corresponds approximately to the carbon dioxide assimilation, including leaf area development, and the $A G E$ function to the reduction in these processes as phenological development proceeds. GI is partly similar to the detailed models except for solar radiation, which in the detailed models drives the carbon assimilation. The FOPROQ model simulates only aboveground biomass and not grain yield, implying an implicit assumption of the harvest index being constant (cf. Hay \& Porter 2006). In summary, the FOPROQ model is expected to consider in particular the effects of variations in spring and summer weather on aboveground biomass yield.

\subsection{Model applications}

The daily weather data used for the climatic indices were taken from the national network of weather stations provided by the Swedish Meteorological and Hydrological Institute (www.smhi.se/en) for the city nearest the long-term experimental sites (Table 1), and in the case of Uppsala, from the Ultuna climate station
(SLU 2009a). In the case of missing values on individual days, data from the previous day were used twice. For longer periods up to $1 \mathrm{wk}$, data were replaced by linear interpolation over time. For missing periods longer than $1 \mathrm{wk}$, data were taken from a nearby climatic station without any modifications. These same weather data were used as input for the climate indices applied to regional yields for the corresponding region (Table 2). The annual mean temperature and precipitation sum for Uppsala, Visby and Lund for $1968-1996$ were $5.6^{\circ} \mathrm{C}$ and $575 \mathrm{~mm}, 7.0^{\circ} \mathrm{C}$ and $558 \mathrm{~mm}$, and $8.1^{\circ} \mathrm{C}$ and $687 \mathrm{~mm}$, respectively. The excess rain in Lund compared to the other sites was mainly due to high precipitation during winter, and the lower annual precipitation in Visby was mainly due to dryer summers. The monthly average temperatures were basically the same for all locations during summer, whereas Uppsala was considerably colder during winter, and Lund was warmer during spring (Table A2 in Appendix 1).

For the growth model (FOPROQ), 3 parameters (Eq. 1) and the initial soil water content were calibrated for each of the 6 datasets (Table A3 in Appendix 1). The target for the simulations was the observed yield, and the parameter values were estimated by optimisation for the maximum coefficient of determination $\left(\mathrm{R}^{2}\right)$. The requirement of a high number of targets and the limited dataset did not allow for cultivar and pre-crop specific calibrations, although the model parameters are believed to depend on these characteristics. For the growth model, the $\mathrm{R}^{2}$-values ranged between 21 and $62 \%$ (Table A3), and 5 to $10 \%$ of the long-term experimental samples were cancelled in the calibration due to extremely low observed yields, regarded to be caused by factors other than those accounted for by the model. The criteria for cancelling an observation were a large difference among replicates, notifications of disturbances (e.g. birds), but also subjective judgements. The start of growth was set equal to the day when the accumulated sum (since 1 January) of temperatures $>0^{\circ} \mathrm{C}$ became larger than 160 degree days $\left({ }^{\circ} \mathrm{D}\right)$ (estimated as $100{ }^{\circ} \mathrm{D}$ less than the calibrated value for observed sowing dates at all sites in the corresponding experiments of spring crops; data not shown). The initial biomass on that day was set arbitrarily to $25 \mathrm{~g}$ dry weight $\mathrm{m}^{-2}$ (similar to observed corresponding values in Kiel, Germany; data not shown) and was the same for all years and all sites. Thus, the growth model simulations did not consider winter impacts other than time for start of growth in spring. The initial soil water content $\left(Q_{\text {Init }}\right)$ was firstly set in accordance to soil type (Table 1 ; this was the only way soil characteristics influenced growth) similar for all years but was later calibrated for 
each site to alter the impact of water availability. The physically unlikely high $Q_{\text {Init }}$ values for Ultuna and Borgeby had no effect other than practically cancelling the influence of water conditions, and the high value for Uppsala County implied a strong reduction of the water influence (Table A3). The observed harvest dates in the experiments were also assumed to be valid for the regional evaluations.

\subsection{Model evaluations}

The model evaluations aimed to give quantitative measures of the influence of the climate index and time, respectively. Statistical significance was evaluated for the hypothesis that the climate index and time coefficients ( $b$ and $c$ ) were equal to 0 . In this way, the following questions were answered: (1) Did the yield $(Y)$ change linearly with time during the period (Eq. 2)? (2) Did the climate index $(X)$ change linearly with time during the period (Eq. 3)? (3) Can the effect of time on yield be distinguished from the effect of climate on yield (Eq. 4)?

$$
\begin{gathered}
Y=a_{t}+b_{t} t \\
X=a_{X t}+b_{X t} t \\
Y_{t X}=a_{t X}+b_{t X} t+c_{t X} X_{i}
\end{gathered}
$$

where $t$ is year, $X_{i}$ is climate index and $a, b$ and $c$ are coefficients. The statistical tests of $b_{t X}$ and $c_{t X}$ were performed using partial sums of squares. The $p$ value of $b_{t X}$ is a measure of the importance of $t$ in addition to $X_{i}$, and the $\mathrm{p}$ value of $c_{t X}$ is a measure of the importance of $X_{i}$ in addition to $t$.

To evaluate the model performance over longer periods, for which the generality of the above linear models was questionable, Eq. 4 was repeated for moving $25 \mathrm{yr}$ periods (using periods shorter than $20 \mathrm{yr}$ influenced the $\mathrm{R}^{2}$ Adj value; see Discussion). A model of high generality would then give high statistical significance (low $\mathrm{p}$ values) and constant $a, b$ and $c$ values for all periods. This approach did not give any statistical tests of the equality of different periods, but gave a quantitative measure of how $a, b$ and $c$ changed over time. Also, the $\mathrm{p}$ values were evaluated this way, and periods with significant relations to time and climate index could be separated from periods of non-significance. Increasing values of $b$ and $c$ would indicate an increasing influence of time and the climate index, respectively, and low $\mathrm{p}$ values would indicate a high statistical significance of this result. A 25 yr period was accepted only if data of $20 \mathrm{yr}$ were available.

The predictability of models was evaluated by means of the adjusted coefficient of determination $\left(\mathrm{R}_{\mathrm{Adj}}^{2}\right)$ in linear regressions with the observed yield as the dependent variable and time and/or $X_{i}$ as the independent variable(s). The significance of a hypothesis being rejected was expressed by the p value (\%) denoted $\mathrm{p}_{b t}, \mathrm{p}_{b X t}$ and $\mathrm{p}_{c t X}$ for Eqs. (2), (3) and (4), respectively (in the figures, the values for $100-\mathrm{p}$ are given). In cases where $>1$ yield observation was available for a single year, the average value was used in the statistical analyses, made with the JMP program package (SAS Institute 2007).

\section{RESULTS}

The winter wheat yield of long-term experiments increased significantly over time at Stenstugu, and also in Ultuna and Borgeby for some periods (Eq. 2; $\mathrm{p}_{b t} \leq$ $5 \%$ in Table A4 in Appendix 1), but not at Säby and for periods before 1950 at Ultuna. The regional yields increased significantly during 1965-1996 in all counties. For the climate indices based on temperature alone, February at Säby, February+March at Ultuna and April temperatures in Gotland (Visby) and Malmöhus (Lund) Counties increased significantly over time, whereas the June temperature in Gotland decreased significantly (Eq. $3 ; \mathrm{p}_{b X t} \leq 5 \%$ in Table A4).

The climate index based on the growth model increased significantly over time in all cases except Borgeby. In the following analyses, these trends in yield and climate indices were not considered explicitly. Instead, trends influenced the time and climate coefficients $\left(b_{t X}\right.$ and $c_{t X}$ ) of the model predicting yield as a function of both time and the climate index (Eq. 4). If the variation in yield could be explained by the climate index, $c_{t X}$ was significantly different from 0 .

\subsection{Long-term experiments}

For the 29 yr period (1968-1996) at Ultuna, the February temperature index was significantly and positively related to the yield $\left(\mathrm{p}_{c t X} \leq 5.0 \%\right.$; Table 4$)$. At Borgeby, January, March and August temperatures all showed significant relations to yield. At Stenstugu, only the July temperature was significantly related to yield, with high temperatures related to low yields. The time coefficient was significant in almost all cases for Stenstugu and Borgeby, but in no case for Ultuna. The model for Ultuna based on the growth model index showed the best predictability of all models, but its predictability for Stenstugu and Borgeby was less than for the simple temperature indices (Table 4). Also, the January-based temperature model at Borgeby showed high predictability; however, this was to a large extent also due to the time variable $\left(\mathrm{p}_{b t X}=2 \%\right.$; Table 4). 
Table 4. Model evaluation parameters for regressions between climate indices, time and winter wheat yields (Eq. 4) for 3 long-term experiments. $R^{2} \operatorname{Adj}(t X)$ : adjusted coefficient of determination $(\%) ; \mathrm{p}_{c t X}$ : probability $(\%)$ for the climate coefficient $c_{t X}=0 ; \mathrm{p}_{b t X}$ : probability $(\%)$ for the time coefficient $b_{t X}=0$. Only p values $<10 \%$ are shown. $(-) \mathrm{p} \geq 10 \%$. Sample sizes $(\mathrm{N})$ were 25 at Ultuna and 26 at Stenstugu and Borgeby. Negative sign after a value denotes a negative relation. Site subscripts refer to yield datasets (see Table A1)

\begin{tabular}{|c|c|c|c|c|c|c|c|c|c|}
\hline \multirow[b]{2}{*}{$X_{T i i} i=$} & \multicolumn{3}{|c|}{$\begin{array}{c}\text { Ultuna }_{3} \\
(1968-1996)\end{array}$} & \multicolumn{3}{|c|}{$\begin{array}{c}\text { Stenstugu }_{1} \\
(1969-1996)\end{array}$} & \multicolumn{3}{|c|}{$\begin{array}{c}\text { Borgeby }_{1} \\
(1968-1996)\end{array}$} \\
\hline & $\mathrm{R}^{2}{ }_{\operatorname{Adj}(t X)}$ & $\mathrm{p}_{c t X}$ & $\mathrm{p}_{b t X}$ & $\mathrm{R}^{2} \operatorname{Adj}(t X)$ & $\mathrm{p}_{c t X}$ & $\mathrm{p}_{b t X}$ & $\mathrm{R}^{2}{ }_{\operatorname{Adj}(t X)}$ & $\mathrm{p}_{c t X}$ & $\mathrm{p}_{b t X}$ \\
\hline September & - & - & - & 17 & - & 2 & 21 & - & 2 \\
\hline October & - & - & - & 22 & - & 1 & 21 & - & 1 \\
\hline November & - & - & - & 23 & - & 1 & 25 & - & 1 \\
\hline December & - & - & - & 18 & - & 1 & 20 & - & 1 \\
\hline January & - & - & - & 18 & - & 1 & 39 & 1 & 2 \\
\hline February & 20 & 2 & - & 22 & - & 2 & 31 & 6 & 1 \\
\hline March & 11 & 7 & - & 18 & - & 2 & 32 & 5 & 2 \\
\hline April & - & - & - & 21 & - & 8 & 28 & - & 6 \\
\hline May & 11 & 7 & - & 18 & - & 1 & 22 & - & 4 \\
\hline June & - & - & - & 28 & $9-$ & 5 & 20 & - & 1 \\
\hline July & - & - & - & 33 & $3-$ & 2 & 19 & - & 1 \\
\hline August & - & - & - & 27 & - & 1 & 32 & 5 & 1 \\
\hline GrowthModel $^{\mathrm{a}}$ & 38 & 1 & - & - & - & - & - & - & - \\
\hline
\end{tabular}

When applying the climate and time model (Eq. 4) to moving 25 yr periods, the predictability based on February temperature was higher before 1980 than after (Fig. 1a). The 2 Uppsala sites (Ultuna and Säby) and Borgeby showed a similar decrease over time for the predictability $\left(\mathrm{R}^{2}{ }_{\text {Adj }}\right)$, the climate coefficient $\left(c_{t X} ;\right.$ Fig. $\left.1 \mathrm{~b}\right)$, and the statistical significance of the climate coefficient $\left(100-p_{c t X i}\right.$ Fig. 1c). For the latter part of the period, the predictability was above 0 only for Ultuna but was mainly due to the time factor (data not shown). The time coefficients of the other 3 sites were significant before 1980, but not after. At Stenstugu, there was no significant relation to the February temperature (Fig. 1c).

For the first half of 1900 s at Ultuna, the yield relation to the February+March temperature sum was steadily significant, and the time factor did not improve the predictability of yield (Fig. 2a). This result was achieved both for the Thule II cultivar and a land race (non-bred local variety), although the latter is regarded to be more frost tolerant (extra line in Fig. 2a). After around 1980, the relation to February+March temperature gradually lost in significance, and model predictability became practically 0 (Fig. 2 b).

\subsection{Regions}

High regional winter wheat yields for the $32 \mathrm{yr}$ period 1965-1996 were related to high winter and spring temperatures for Uppsala and Malmöhus Coun- ties, although less significant for Malmöhus (Table 5). For the island of Gotland, the winter temperature was of less importance and instead high summer temperatures (June and July) were significantly related to low yields. Due to the strong relation to time, the model

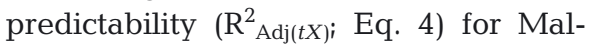
möhus County was essentially higher than for Uppsala and Gotland Counties (Table 5). Relations to temperature and time were basically similar to those of the long-term experiments (Table 4), except that they were more pronounced for regional yields.

The relations between March temperature and regional winter wheat yields in Uppsala were significant $\left(100-\mathrm{p}_{c t X}>\right.$ $95 \%$; Fig. 3a) for all 25 yr periods. The predictability deceased from above $50 \%$ to $25-30 \%$, and the climate coefficient $\left(c_{t X}\right)$ decreased by half. The relation of yields to time was usually non-significant and varied considerably (Fig. 3a). In comparison with long-term experiments (Fig. 1), the temperature relations of the regional yields were more often statistically significant.

The climate index derived by the growth model predictions and regional yields in Gotland County showed a strong relation. The climate coefficient was statistically significant, and the model predictability was high $\left(\mathrm{R}^{2}{ }_{\mathrm{Adj}(t X)}=45-60 \%\right)$ for the whole period (Fig. 3b). For this model, the relation to time was not significant, indicating that the growth model predictions to a significant degree covered trends in yield. However, the climate coefficient $\left(c_{t X}\right)$ decreased over time, indicating that the growth model predictions tended to overestimate yields in the latter periods. The predictability of the corresponding model for the long-term experiment at Stenstugu was lower $(<40 \%)$, and the relation was statistically significant only until 1985 (data not shown).

In Gotland County, the model based on the June temperature index had equally high predictability (the extra line in Fig. 3b) as that based on the growth model simulations. However, for the periods in the end (centred around 1993-1996), the predictability (and significance) decreased to very low values. The largest difference compared with the growth model applications were that the time coefficient was strongly significant for almost all periods for the June model, whereas it was never significant for the growth model. If the June temperature index was replaced by the July index, the 4 last periods achieved high yield predictability (40$50 \%$ ), and the climate and time relations were signifi- 

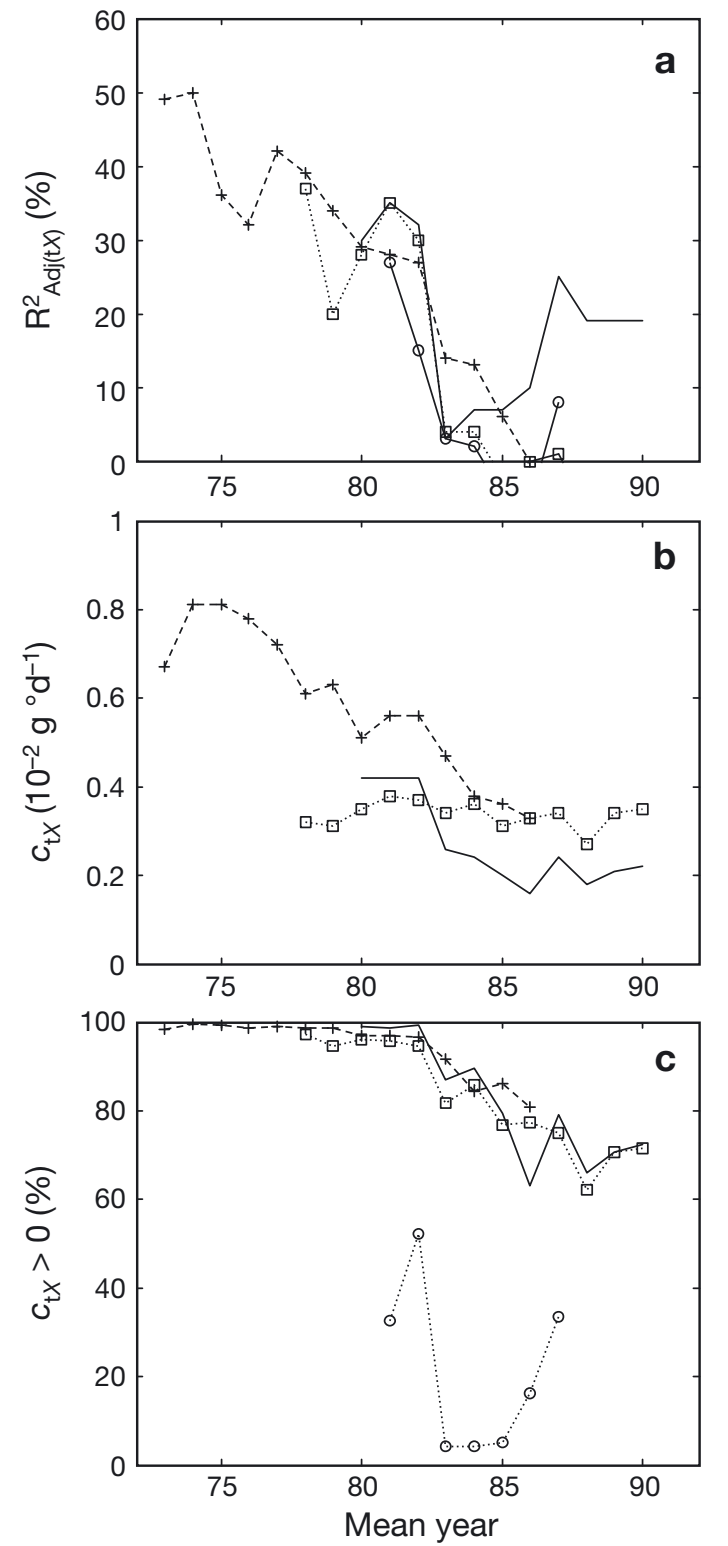

Fig. 1. Model evaluation parameters of regressions between February temperature sums, time and annual winter wheat yield (Eq. 4) for floating 25 yr periods for Ultuna 3 (solid line), Säby ( $\square$ ), Stenstugu ${ }_{1}(0)$ and Borgeby 1 (+). (a) Adjusted coefficient of determination $\left(\mathrm{R}^{2}{ }_{\operatorname{Adj}(t X) ;} \%\right)_{i}$ (b) climate coefficient $\left(c_{t X i} 10^{-2} \mathrm{~g}^{\circ} \mathrm{d}^{-1}\right) ;\left(\right.$ c) significance of climate coefficient $c_{t X}>0$ $\left(100-\mathrm{p}_{c t X ;} \%\right)$. The $X$-axis is the average year of the period concerned. $c_{t X}$ of Stenstugu ${ }_{1}$ is not plotted in (b) due to its low significance values in (c)

cant. However, for the earlier periods, the predictability and significance were less than for the June model. For the model based on June+July temperatures, the predictability was lower throughout (data not shown).

In summary, the strongest influence of climate was estimated by the growth model predictions of regional yields in Gotland County, in terms of the highest predictability $(54 \%)$, high significance of the climate coef-

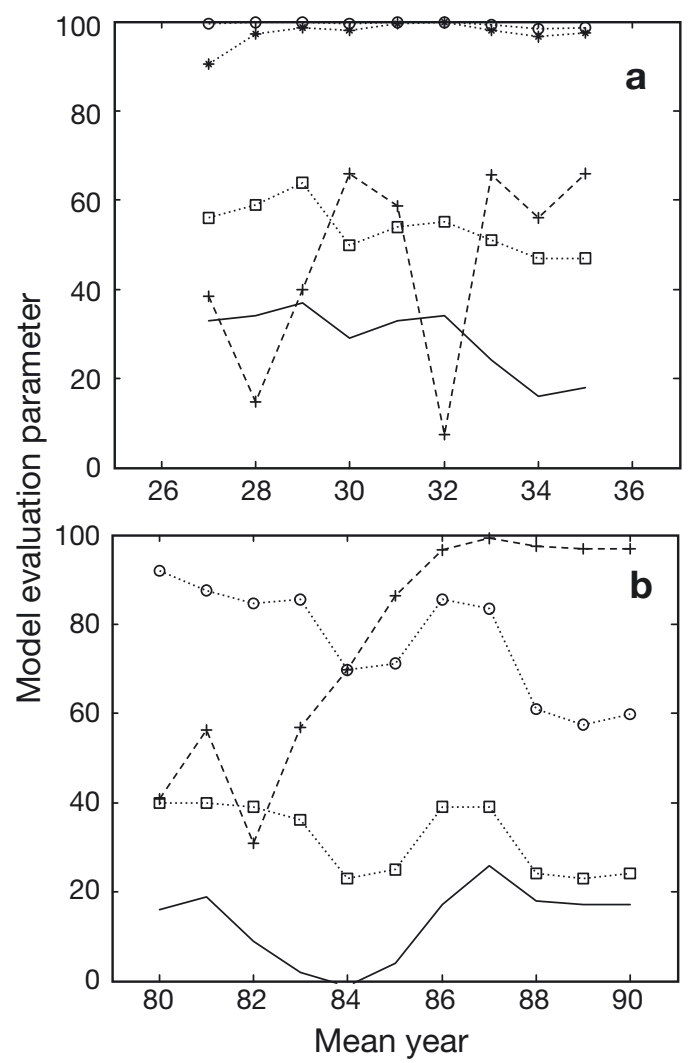

Fig. 2. Model evaluation parameters of regressions between $X_{T \text { Feb+March }}$ time and annual winter wheat yield (Eq. 4) for moving $25 \mathrm{yr}$ periods for 2 periods and sites. Units-( $\square) 10^{-2} \mathrm{~g}^{\circ} \mathrm{D}^{-1}$; all other symbols: \%.(a) Ultuna ${ }_{1}, 1915-1947$, Thule II cultivar; (b) Ultuna 3 , 1968-2002, changing cultivar. Solid line: coefficient of determination $\left(\mathrm{R}^{2}{ }_{\text {Adj }(t X) ;} \%\right) ;(\square)$ : climate coefficient $\left(c_{t X} ; 10^{-2} \mathrm{~g}\right.$ $\left.{ }^{\circ} \mathrm{d}^{-1}\right) ;(0)$ significance for $C_{t X}>0\left(100-\mathrm{p}_{c t X i} \%\right) ;(+)$ significance for the time coefficient $b_{t X}>0\left(100-\mathrm{p}_{b t X i} \%\right)$. The $X$-axis is the average year of the period concerned. (*) in (a) (close to 100) is $100-\mathrm{p}_{c t X}$ for a land race (non-bred local variety) (Ultuna ${ }_{2}$ )

ficient, low significance of the time coefficient and a stable value of the climate coefficient over years $( \pm 18 \%$; Fig. 3b).

\subsection{Trends}

The difference between the time coefficient of the yield being only a function of time $\left(b_{t}\right.$ in Eq. 2$)$ and the time coefficient of the time and climate index model ( $b_{t X}$ in Eq. 4 ) is a measure of the climate influence on the trends. The climate index models revealing the highest significance and the models based on the growth model applications are evaluated for this difference in Table 6 .

The strongest effect of climate was found for the growth model application to Gotland County. The yield increased by $1.46 \% \mathrm{yr}^{-1}$, of which almost two-thirds could be attributed to the estimated climate factors (ex- 
Table 5. Model evaluation parameters for regressions between climate indices, time and regional annual winter wheat yields (Eq. 4) for 3 counties (Statistiska centralbyrån [Statistics Sweden]: www.scb.se). $\mathrm{R}^{2}{ }_{\text {Adj }(t X)}$ : coefficient of determination (\%); $\mathrm{p}_{c t X}$ : probability (\%) for the climate coefficient $c_{t X}=0 ; \mathrm{p}_{b t X}$ : probability $(\%)$ for the time coefficient $b_{t X}=0$. Only p values $<10 \%$ are shown. Sample size $(\mathrm{N})$ was 32 for all counties/periods. Negative sign after a value denotes a negative relation

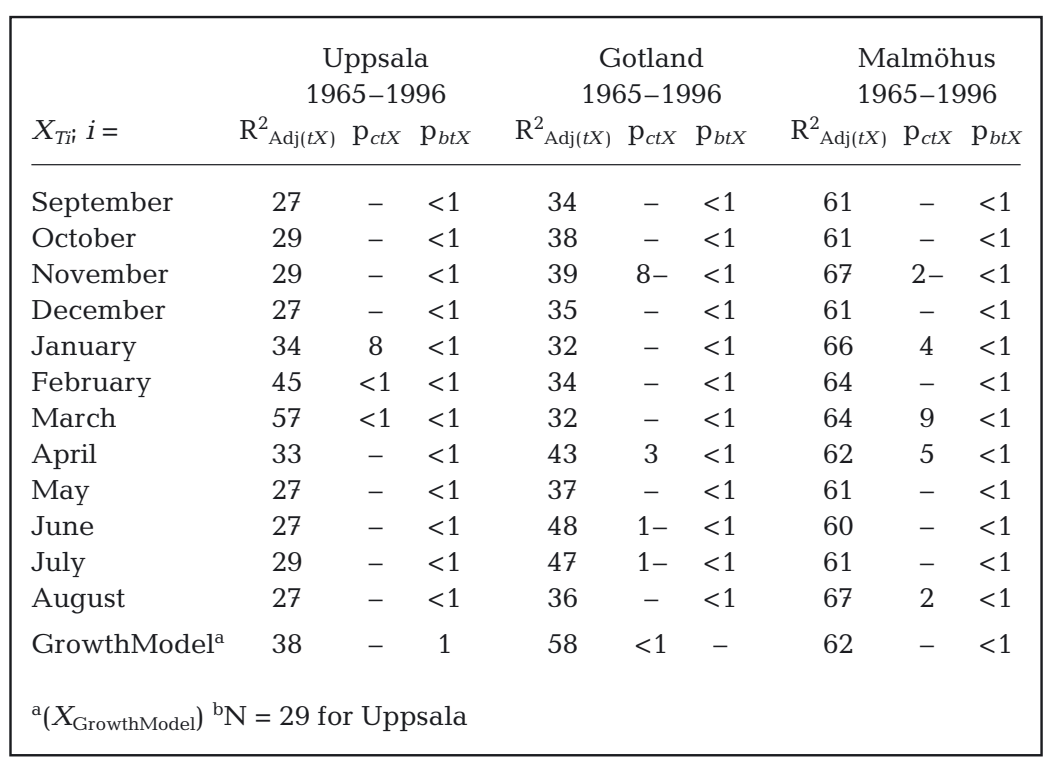

plained by simulated increased water availability) and the rest to other factors. The time trend in yield was least in Uppsala County, and the relative contribution of the climate was lower than for Gotland. In Malmöhus County, the trends were strongest, especially in absolute values, and the contribution of climate was the least, both in absolute and relative terms (less than one-tenth). The relative trend ( $\%$ yield change $\mathrm{yr}^{-1}$ ) of the long-term experiment of Stenstugu was lower than for the regional yields for Gotland ( $b_{t} \%$ in Table 6$)$, whereas it was higher for Ultuna than Uppsala County, especially for the growth model (explained by changes in temperature and solar radiation).

\section{DISCUSSION}

\subsection{Trends}

The relations between simple temperature indices and yield examined in this

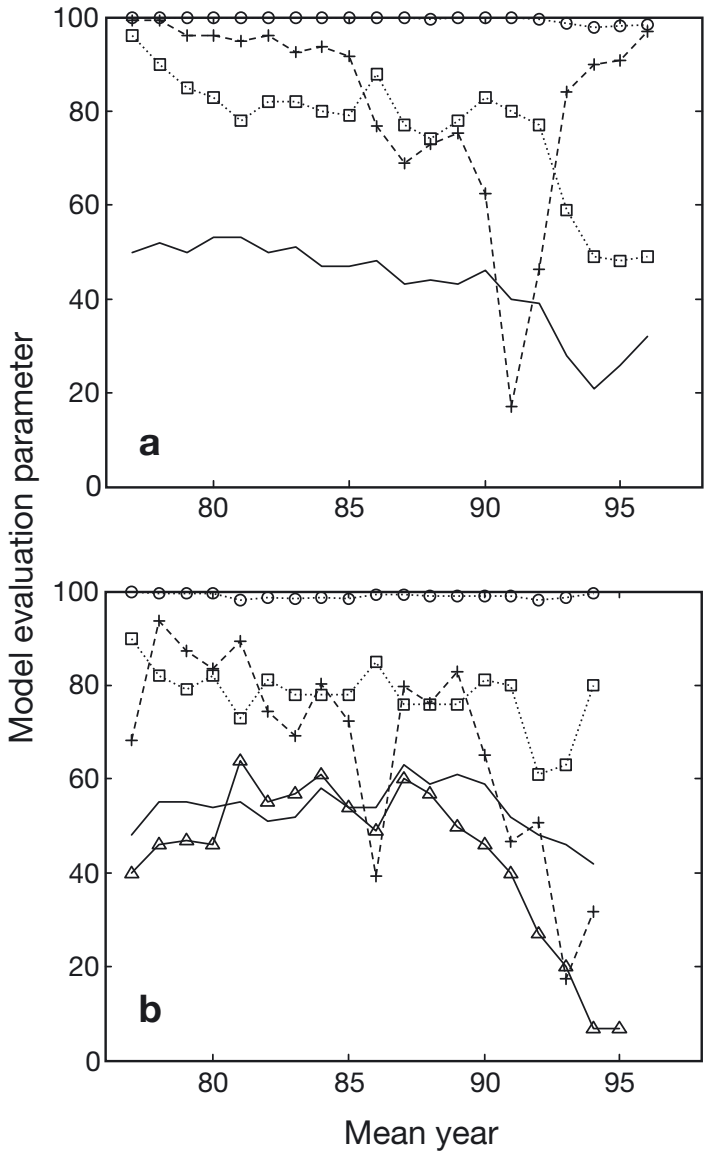

study were similar to those for the end of the 1800s and the first half of the 1900s (Wallén 1917, 1920, Hallgren 1947 ) in that the strongest relations were found for Gotland County, and that winter temperatures were most important in Uppsala County (Table 5). In Malmöhus County, the relations to temperature seemed more complicated. The most clear change over time was that a pronounced positive relation to high winter temperatures in Gotland disappeared in our study, i.e. by the end of the 1900 s, and that the negative relation to summer temperatures (especially June) became stronger. At Ultuna, the positive correlation between yield and winter temperatures was stable during the beginning of the 1900s but became weak by the end of the century (Fig. 2). However, at the county level, this decline was less clear (Fig. 3). A comparison between winter wheat yield and

Fig. 3. Model evaluation parameters for regressions between $X_{i}$, time and annual winter wheat yield (Eq. 4) for moving 25 yr periods. (a) Uppsala County, 1965-2008, $X_{\text {Tmarchi }}$ (b) Gotland County, 1965-2006, $X_{\text {GrowthModel }}$. Units: ( $\square$ in a) $10^{-2} \mathrm{~g}^{\circ} \mathrm{D}^{-1}$; ( $\square$ in b) dimensionless, scaled by a factor of 100; all other symbols: \%. Units: ( $\square$ in a) $10^{-2} \mathrm{~g}^{\circ} \mathrm{D}^{-1}$; ( $\square$ in b) dimensionsless, scaled by a factor of 100; all other symbols: \%. Solid line: coefficient of determination $\left(\mathrm{R}^{2}{ }_{\text {Adj }(t X) ;} \%\right)$; $(\square)$ climate coefficient ( $c_{t X}$; units differ); (O) significance for $c_{t X}>0\left(100-\mathrm{p}_{c t X} ; \%\right),(+)$ significance for the time coefficient $b_{t X}>0\left(100-\mathrm{p}_{b t X} ; \%\right) .(\Delta)$ in $(b)$ is $\mathrm{R}^{2} \operatorname{Adj}(t X)(\%)$ for $X_{T J u n e}$. The $X$-axis is the average year of the period concerned 
Table 6. Time coefficients $b_{t}$ of the time model (Eq. 2), and $b_{t X}$ of the time and climate model (Eq. 4), expressed as change of yield $\mathrm{yr}^{-1}$ divided by average yield $(\%)$, for the most significant model applications of Tables 4 \& 5 (sites refer to 1968-1996 and regions to 1965-1996). ${ }^{*}$ Significantly different from $0(\mathrm{p}<0.05) . b_{t}\left(\mathrm{~kg} \mathrm{ha}^{-1} \mathrm{yr}^{-1}\right)$ is taken from Table A4. $x_{\text {Frac }}(\%)$ is the relative contribution of the climate coefficient to the total trend $\left[100\left(1-b_{t X} / b_{t}\right)\right]$

\begin{tabular}{|c|c|c|c|c|}
\hline$X_{T i i} i=$ & $b_{\mathrm{t}}$ & $b_{t} \%$ & $b_{t X} \%$ & $x_{\text {Frac }}$ \\
\hline \multicolumn{5}{|l|}{ Site } \\
\hline \multicolumn{5}{|l|}{ Ultuna } \\
\hline February & 21.2 & 0.44 & 0.28 & 36 \\
\hline GrowthModel $^{\mathrm{a}}$ & $56.7^{*}$ & $1.08^{*}$ & 0.50 & 54 \\
\hline \multicolumn{5}{|l|}{ Stenstugu } \\
\hline July & $67.1^{*}$ & $1.34^{*}$ & $1.18^{*}$ & 12 \\
\hline GrowthModel $^{\mathrm{a}}$ & $63.4^{*}$ & $1.29^{*}$ & 0.94 & 27 \\
\hline \multicolumn{5}{|l|}{ Borgeby } \\
\hline January & $63.3^{*}$ & $1.31^{*}$ & $1.04^{*}$ & 21 \\
\hline GrowthModel $^{\mathrm{a}}$ & 35.9 & 0.68 & 0.69 & -1 \\
\hline \multicolumn{5}{|l|}{ County } \\
\hline \multicolumn{5}{|l|}{ Uppsala } \\
\hline March & $62.6^{*}$ & $1.34^{*}$ & $1.01^{*}$ & 24 \\
\hline GrowthModel $^{\mathrm{a}}$ & $57.6^{*}$ & $1.20^{*}$ & $0.97^{*}$ & 19 \\
\hline \multicolumn{5}{|l|}{ Gotland } \\
\hline June & $58.4^{*}$ & $1.46^{*}$ & $1.09^{*}$ & 25 \\
\hline GrowthModel $^{\mathrm{a}}$ & $58.4^{*}$ & $1.46^{*}$ & 0.52 & 64 \\
\hline \multicolumn{5}{|l|}{ Malmöhus } \\
\hline August & $89.9^{*}$ & $1.56^{*}$ & $1.42^{*}$ & 9 \\
\hline GrowthModel $^{\mathrm{a}}$ & $89.9^{*}$ & $1.56^{*}$ & $1.46^{*}$ & 6 \\
\hline${ }^{\mathrm{a}} X_{\text {GrowthModel }}$ & & & & \\
\hline
\end{tabular}

duration of winter in Sweden by Holmer (2008) suggested that winter length has a pronounced influence on yield at mean annual temperatures below 5 or $6^{\circ} \mathrm{C}$, which corresponds to the climate of the Uppsala region (Table A2), in which yields were most influenced by winter temperatures in our study.

Yield time trends in the long-term experiments were almost non-existent for the periods before 1915 (Wallén 1920) and at Ultuna until 1945 (Torssell 1953, this study). For the latter part of the 1900s, the trends were positive at Stenstugu and Borgeby, whereas at Ultuna the trends remained non-significant (Table A4). In contrast, on the regional scale there were positive trends already at the beginning of the century in southern Sweden, and by the latter half of the century, these trends were also pronounced in Gotland (cf. Michael 2002) and Uppsala Counties, although they were still most significant in the south.

The positive time coefficients of most models were significant for regional yields. In addition to technical, socio-economic and other factors, these time factors were also influenced by a gradual increase in the atmospheric $\mathrm{CO}_{2}$ concentration. However, this influence was expected to be of minor importance (cf. Berntsen et al. 2006, Ewert et al. 2007).
Annual trends in regional yields from 1965-1996 ranged between 58 and $90 \mathrm{~kg} \mathrm{ha}^{-1}$, and for the longterm experiments, 57 and $63 \mathrm{~kg} \mathrm{ha}^{-1}$ (Table 6). The trends were highest in southern Sweden in Mamöhus County and at Borgeby, but the contributions of climate were estimated to be only 9 to $13 \mathrm{~kg} \mathrm{ha}^{-1} \mathrm{yr}^{-1}$ (with the reservation that the model predictability was low). The estimated contribution of climate was higher in Gotland County and at Ultuna: 37 and $31 \mathrm{~kg} \mathrm{ha}^{-1}$ $\mathrm{yr}^{-1}$, respectively. Hence, the contribution of other factors would have been at least 20 to $25 \mathrm{~kg} \mathrm{ha}^{-1} \mathrm{yr}^{-1}$, which is of similar magnitude as trends attributed to genetic changes in controlled experiments of winter wheat in Finland during a corresponding period (17 to $25 \mathrm{~kg} \mathrm{ha}^{-1} \mathrm{yr}^{-1}$; Peltonen-Sainio et al. 2009a). However, our trends partly included effects of changed variety properties, e.g. frost tolerance.

\subsection{Sites versus regions}

Although many more factors were expected to influence the regional yields (cf. Bakker et al. 2005, Jaggard et al. 2007, Peltonen-Sainio et al. 2009b) than in the controlled experiments, the climate indices improved model predictability more for the regional yields (Tables 4 \& 5; Figs. 1-3). A possible explanation is that commercial cropping was more adapted to utilise the climatic potential than the controlled and more fixed managed experiments. On a regional level, the effects of local disturbances are aggregated (cf. Górski \& Górska 2003) and might be diluted, thus allowing for clearer climatic responses. However, we can easily find factors that certainly have disturbed the regional yield-climate relation in our study, where weather records of a single location were compared with the yield of the whole county. The approach was partly acceptable, however, as most areas under cultivation are relatively flat and the local temperature observations might be fairly representative of year to year variations on a regional scale. The meteorological stations were fairly close (1 to $20 \mathrm{~km}$ ) to the experimental sites and thus probably better represented the sites than the regions. The area cultivated with winter wheat varied from year to year, especially in Uppsala County (Table 2), where the area was almost 0 in 1982 and 1985 (in 2000 the area was also small, and in Gotland it was almost 0 in 1986). In these cases, a spring crop probably replaced it, and the regional winter wheat yield statistics miss the strongest influences of unfavourable winters. The trend of increased area for winter wheat in Malmöhus and decreased area in Gotland would also have changed the soil conditions in a systematic way (Table 2). Nevertheless, the regional yields were more strongly related to climate than the 
yields of long-term experiments. This is in agreement with previous studies (cf. Bakker et al. 2005), indicating that the influence of climate on yield is more complicated to predict on a local scale.

\subsection{Evaluation strategy}

By shifting from 1 moving 25 yr period to the next, 1 value out of 25 was changed. Nevertheless, in case of extreme values, this resulted in rapid shifts in the $R^{2}$ values (cf. Fig. 1a). By using shorter periods of $\leq 15 \mathrm{yr}$, the $R^{2}$ values became very sensitive to single extreme values, whereas periods $\geq 20$ yr gave more stable and similar results (data not shown). Hence the criteria used for selecting a certain period could strongly influence the evaluation of model predictability depending on extreme values. For this reason, we used a fixed and long period, whereas a very different approach was applied by Peltonen-Sainio et al. (2009a), who selected 3 periods (1970-1980, 1981-1994 and 1995-2005) based on trends and technical and socio-economic factors. Since the 25 yr periods partly included the same years, we could not statistically evaluate the difference between periods; we could only show that yield was significantly related to the climate index for some periods, but not for others. For this reason, as an alternative approach for investigating changes in the yield to climate relation over time, we applied a model similar to Eq. 4 into which was added a term for time by climate interaction $\left(d \times t \times X_{i}\right)$. By this model, significant levels $(\mathrm{p}<5 \%)$ of changing relations over time were found based on November and June temperatures at Ultuna, January temperature at Stenstugu, September temperature at Borgeby, and the growth model-derived index at Borgeby. February temperature relations were less significantly changed over time ( $\mathrm{p}$ ranged from 12 to $22 \%$ ), thus not confirming the statistical significance on a $5 \%$ level of the changed relation between February temperature and yield shown in Fig. 1. In no case was the interaction coefficient $(d)$ significantly different from 0 for the relations to regional yields (data not shown).

Yield trend studies in Finland by Peltonen-Sainio et al. (2009a) used 5 yr averages. Applying annual values, as in our study, gives extreme values a greater influence and possibly decreases predictability compared to the higher aggregated approach (cf. Bakker et al. 2005). A good fit of averaged values might also reflect a possible relation between yields and preceding crop.

Menzhulin et al. (2009) applied a multiregression approach based on a single month's temperature and precipitation to the same regional yield data as we used. For 1965-2005 and Uppsala County, their model based on February and March temperatures and the precipitations of September (previous year), February,
May and August $\left(\mathrm{R}^{2}\right.$ Adj $\left.=0.54\right)$ gave similar predictability as our model based on only March temperature (Table 5). It should be noted that our predictability included effects of trends, whereas their study compensated for trends. For Gotland County, the summer temperatures were significant for both studies; however, their application also made use of November and February temperatures, and May and June precipitation $\left(\mathrm{R}^{2}\right.$ Adj $\left.=0.66\right)$. For Malmöhus County, both studies revealed a more varied relation to monthly temperatures than for the other counties.

In summary for our study, the climate and time model (Eq. 4) based on the growth model simulations improved the yield predictability in Gotland County, compared to all other applications (Table 5). In this case, the climate coefficient $\left(c_{t X}\right)$ was significant and fairly constant over time (Fig. 3b). Also, the time coefficient was non-significant, indicating that the climate factor to a large extent explained the changes over time. Thus, the model evaluates the climate factor to be important in comparison with other factors, and the model might be regarded as being applicable to climate change assessments in Gotland County, if the water availability remains an important factor. In contrast, the growth model did not improve the predictability for Malmöhus County, suggesting either that the variation in summer conditions was of less importance, or that a correct parameterisation would need more data, or that an alternative model structure (e.g. Berntsen et al. 2006) would be needed for climate change assessments of winter wheat yield in this region (cf. discussion by Challinor et al. 2009).

\section{CONCLUSIONS}

A major part of the positive winter wheat yield trend in Gotland (island in the Baltic Sea), and a substantial part in Uppsala County (central Sweden) were estimated to be due to a changing climate. In Gotland, this might be explained by increased water availability, whereas in Uppsala County, by increased winter temperatures. However, the changing climate contribution to yield trends in southern Sweden was estimated to be small (1 exception). For all regions, the relationships to winter temperatures seemed to become weaker over time. The relationships also differed among regions. For climate change assessments of winter wheat yield in central Sweden in the near future, the growth model considering temperature, solar radiation and water conditions during spring and summer would also include processes of overwintering (cf. Bergjord et al. 2008). For assessments in southern Sweden, the current growth model would need to be recalibrated, changed or replaced. 
Acknowledgements. We thank T. Lechovius (SLU) for providing yield data from the SLU database. The study was financed by the Environmental Monitoring and Assessment Programme at SLU and the Swedish Board of Agriculture.

\section{LITERATURE CITED}

Andersson T, Wallgren B (1991) Växföljder med olika behandlingar av skörderester (Crop rotations with different treatments of crop residues). Rep 29. Department of Crop Production, Swedish University of Agricultural Sciences, Uppsala, (In Swedish with English summary)

Angus JF, Kornher A, Torssell BWR (1980) A systems approach to estimation of Swedish ley production: progress report 1979/80. Rep 85. Department of Crop Production, Swedish University of Agricultural Sciences, Uppsala

Arrhenius O (1926) Vattnet som vegetationsfaktor (Water as a vegetation factor). The Royal Swedish Academy of Agriculture and Forestry. Handl Tidskr 65:37-51 (in Swedish)

Bakker MM, Govers G, Ewert F, Rounsevell M, Jones R (2005) Variability in regional wheat yields as a function of climate, soil and economic variables: assessing the risk of confounding. Agric Ecosyst Environ 110:195-209

Bergjord AK, Bonesmo H, Skjelvåg AO (2008) Modelling the course of frost tolerance in winter wheat. I. Model development. Eur J Agron 28:321-330

Berntsen J, Petersen BM, Olesen JE (2006) Simulating trends in crop yield and soil carbon in a long-term experimenteffects of rising $\mathrm{CO}_{2}, \mathrm{~N}$ deposition and improved cultivation. Plant Soil 287:235-245

Challinor AJ, Ewert F, Arnold S, Simelton E, Fraser E (2009) Crops and climate change: progress, trends, and challenges in simulating impacts and informing adaptation. J Exp Bot 60:2775-2789

Chauhan S, Khandelwal RS, Prabhu KV, Sinha SK, KhannaChopra R (2005) Evaluation of usefulness of daily mean temperature studies on impact of climate change. J Agron Crop Sci 191:88-94

Eckersten H, Noronha-Sannervik A, Nyman P, Torssell B (2001) Modelling mass flows in soil plant systems using Matlab/ Simulink. In: Björneå TI (ed) Nordic MATLAB conferenceprogram \& proceedings. COMSOL AS, Trondheim 17-18 October, Oslo, p 44-49

Eckersten H, Andersson L, Holstein F, Mannerstedt Fogelfors B, Lewan E, Sigvald R, Torssell B (2007a). Bedömningar av klimatförändringars effekter på växtproduktion inom jordbruket i Sverige (Evaluation of climate change effects on crop production in Sweden). Bilaga 24 i: Sverige inför klimatförändringarna - hot och möjligheter, SOU 2007:60, Bilagedel B, bilaga B 23-27:26-277 (in Swedish with English summary)

Eckersten H, Torssell B, Kornher A, Boström U (2007b) Modelling biomass, water and nitrogen in grass ley: estimation of N uptake parameters. Eur J Agron 27:89-101

Eckersten H, Karlsson S, Torssell B (2008). Climate change and agricultural land use in Sweden - a literature review. Rep 7. Department of Crop Production Ecology, Swedish University of Agricultural Sciences, Uppsala

Eriksson J, Andersson A, Andersson R (1997) Tillståndet i svensk åkermark (Status of Swedish agricultural soils). Rep 4778, Swedish Environmental Protection Agency, Stockholm (in Swedish)

Ewert F, Rounsevell MDA, Reginster I, Metzger MJ, Leemans R (2005) Future scenarios of European agricultural land use. I. Estimating changes in crop productivity. Agric Ecosyst Environ 107:101-116
Ewert F, Porter JR, Rounsevell MDA (2007) Crop models, $\mathrm{CO}_{2}$, and climate change. Science 315:459-460

Fagerberg B, Torssell B (1995) Estimation of variation in growth potential of leys with different red clover contents, nitrogen applications and cutting regimes. Wirtsch Futter 41:145-162

> Górski T, Górska K (2003) The effects of scale on crop yield variability. Agric Syst 78:425-434

Hallgren G (1947) Studies on the influence of precipitation on crop yields in Sweden with special reference to field irrigation. K Lantbrukshögskol Ann 14:173-298

Hay RKM, Porter JR (2006). The physiology of crop yield, 2nd edn. Blackwell Publishing, Oxford

> Herrmann A, Kelm M, Kornher A, Taube F (2005a) Performance of grassland under different cutting regimes as affected by sward composition, nitrogen input, soil conditions and weather - a simulation study. Eur J Agron 22:141-158

> Herrmann A, Kornher A, Taube F (2005b) A new harvest time prognosis tool for forage maize production in Germany. Agric For Meteorol 130:95-111

Hollins PD, Kettlewell PS, Peltonen-Sainio P, Atkinson MD (2004) Relationships between climate and winter cereal grain quality in Finland and their potential for forecasting. Agric Food Sci 13:295-308

> Holmer B (2008) Fluctuations of winter wheat yields in relation to length of winter in Sweden 1866 to 2006. Clim Res 36:241-252

Jaggard KW, Qi A, Semenov MA (2007) The impact of climate change on sugarbeet yield in the UK: 1976-2004. J Agric Sci 145:367-375

MathWork (2005) Matlab version 7.1 with Simulink, release 14. www.mathworks.com/

Mearns LO, Rosenzweig C, Goldberg R (1992) Effect of changes in interannual climatic variability on CERESwheat yields: sensitivity and $2 \times \mathrm{CO}_{2}$ general-circulation model studies. Agric For Meteorol 62:159-189

Menzhulin GV, Pavlovsky AA, Shamshurina NV (2009) Statistical modelling of crop productivity anomalies based on ensemble approach. Bull St Petersbg State Univ 7:76-85 (in Russian)

Michael D (2002) Höst- och vårveteodlingen på Gotland 1913-1999 och klimatets betydelse för densamma (Winter and spring wheat cultivation in Gotland 1913-1999, and the influence of climate). Projektarbete (B310) vid Institutionen för Geovetenskaper/Naturgeografi, University of Gothenburg (in Swedish)

Nyström S (1974) Skördeutveckling i några långvariga växtföljdsförsök (Yield development in some long-term rotation experiments). Rep R Agric Coll Sweden Ser A 219 (in Swedish with English summary)

Olesen JE, Jensen T, Petersen J (2000) Sensitivity of fieldscale winter wheat production in Denmark to climate variability and climate change. Clim Res 15:221-238

Peltonen-Sainio P, Jauhiainen L, Laurila IP (2009a) Cereal yield trends in northern European conditions: changes in yield potential and its realisation. Field Crops Res 110:85-90

Peltonen-Sainio P, Jauhiainen L, Venäläinen A (2009b) Comparing regional risks in producing turnip rape and oilseed rape-today in light of long-term datasets. Acta Agric Scand Sect B Plant Soil Sci 59:118-128

> Persson T, Bergkvist G, Kätterer T (2008) Long-term effects of crop rotations with and without perennial leys on soil carbon stocks and grain yields of winter wheat. Nutr Cycl Agroecosyst 81:193-202

Ragasits I, Debreczeni K, Berecz K (2000) Effect of long-term fertilisation on grain yield, yield components and quality parameters of winter wheat. Acta Agron Hung 48:149-154 
Ritchie JT, Otter S (1985) Description and performance of CERES-wheat: a user-oriented wheat yield model. In: Willis WO (ed) ARS wheat yield project, ARS-38. ARS, USDA, Washington, DC, p 159-175

SAS Institute (2007) JMP user guide, Release 7. SAS Institute, Cary, NC

SLU (Sveriges Lantbruksuniversitet) (2009a) Ultuna climate station. SLU, Uppsala. http://grodden.evp.slu.se/slu_ klimat/

SLU (2009b) Fältforsk's database. SLU, Uppsala. www.ffe.slu. se/eng/

Torriani DS, Calanca P, Schmid S, Beniston M, Fuhrer J (2007) Potential effects of changes in mean climate and climate variability on the yield of winter and spring crops in Switzerland. Clim Res 34:59-69

Torssell B (1953) Några studier över genotypisk och fenotypisk variation hos åkerbruksväxterna och dess betydelse för odlingsvärdet (Studies on crop genotypic and phenotypic variations and their significance for yield). Svensk Utsädesför Tidskr 63:416-439 (in Swedish)

Torssell BWR (1989) Väderlek och växtproduktion. Ett tillämpningsområde i förvandling (Weather and crop production - an application area under development). Nor Landbruksforsk (Suppl 5):117-129 (in Swedish)

Torssell BWR, Kornher A (1983) Validation of a yield prediction model for temporary grasslands. Swed J Agric Res 13: 125-135

Torssell B, von Rosen D, Olofsson PO, Danell S, Pettersson A, Rösiö G, Worwerk P (1986) Analys av skördevariationer med utgångspunkt i de objektiva skördeuppskattningarna (Analysis of yield variations based on objective yield estimates). Delrapport 2. SVAROS, Statistiska Centralbyrån (SCB), Stockholm (in Swedish)

Wallén A (1917) Sur la corrélation entre les récoltes et les variations de la température et de l'eau tombée en Suede. K Vetenskapsakad Handl (Stockholm) 57:8

Wallén A (1920) Le influence de la température et de l'eau tombée sur les récoltes de quelques varietetes de froment a Svalöv et a Ultuna. Geogr Ann 2:333-357

Weir AH, Bragg PI, Porter JR, Rayner JH (1984) A winter wheat crop simulation model without water or nutrient limitation. J Agric Sci 102:371-382

\section{APPENDIX 1.}

Table A1. Winter wheat long-term trial selected for climate-time models. Except for Ultuna ${ }_{1,2}$, data were taken from the field trial database conducted by SLU (2009b). SOR: spring oilseed rape, WOR: winter oilseed rape. Subscripts 1-4 define the datasets used in the model applications

\begin{tabular}{|c|c|c|c|c|c|c|c|}
\hline Site & $\begin{array}{l}\text { Climate } \\
\text { application }\end{array}$ & $\begin{array}{c}\text { Crop } \\
\text { rotation }\end{array}$ & $\begin{array}{c}\text { Fertilisation } \\
\left(\mathrm{kg} \mathrm{N} \mathrm{ha}^{-1} \mathrm{yr}^{-1}\right)\end{array}$ & Cultivar & Pre-crop & Period & Missing years \\
\hline Ultuna $_{1}$ & Temp. index & $7 \mathrm{yr}^{\mathrm{b}}$ & a & Thule II & Fallow & $1915-1947$ & \\
\hline Ultuna $_{2}$ & Temp. index & $7 \mathrm{yr}^{\mathrm{b}}$ & $\mathrm{a}$ & Land race & Fallow & $1915-1947$ & \\
\hline Ultuna $_{3}$ & Temp. index & $\mathrm{B}^{\mathrm{c}}$ & 90 & Varied & Pea & $1968-2002$ & $1981,84,85,87,2001$ \\
\hline Ultuna $_{4}$ & Growth model & $\mathrm{C}^{\mathrm{d}}$ & 90 & Varied & SOR & $1968-2005$ & $1981,84,85,87,2001$ \\
\hline Säby & Temp. index & Mean $^{\mathrm{e}}$ & 120 & Varied & WOR & 1966-2002 & $1981,84,87,2001$ \\
\hline Stenstugu $_{1}$ & Temp. index & $A^{f}$ & 120 & Varied & WOR & 1969-2005 & $1979,85,2000-03$ \\
\hline Stenstugu $_{2}$ & Growth model & Mean $^{g}$ & 120 & Varied & WOR & 1969-2005 & $1979,85,2000-03$ \\
\hline Borgeby $_{1}$ & Temp. index & $\mathrm{C}^{\mathrm{h}}$ & 120 & Varied & Pea & 1961-1998 & $1985,94,95$ \\
\hline Borgeby $_{2}$ & Growth model & $\mathrm{C}^{\mathrm{h}}$ & 120 & Varied & WOR & 1961-1996 & $1964,65,71,75,78,83,85,94,95$ \\
\hline \multicolumn{8}{|c|}{ a Ordinary large manure application } \\
\hline \multicolumn{8}{|c|}{${ }^{b}$ Variety trial: Fallow (F, crop rotation B), winter wheat (WW), spring barley (SB), Ley (L), L, L, Oats (O) } \\
\hline \multicolumn{8}{|c|}{${ }^{\mathrm{c}}$ Rotation trial (R4-0007, crop rotation C): F, SOR, WW, SB, WW, Pea (P), WW, O } \\
\hline \multicolumn{8}{|c|}{${ }^{\mathrm{d}}$ Rotation trial (R4-0007): F, SOR, WW, SB, L, WW, P, O } \\
\hline \multicolumn{8}{|c|}{${ }^{\text {e}}$ Rotation trial (1103-5, crop rotation A): average of 3 crop rotations } \\
\hline \multicolumn{8}{|c|}{${ }^{\mathrm{f}}$ Rotation trial (1103-4): WOR, WW, O, SB, L, L } \\
\hline \multicolumn{8}{|c|}{ gRotation trial (1103-4, crop rotation C): average of 3 crop rotations } \\
\hline \multicolumn{8}{|c|}{${ }^{\mathrm{h}}$ Rotation trial (R4-0002): WW, sugar beat, $\mathrm{SB}, \mathrm{L}$, WOR, WW, spring wheat, $\mathrm{P}$} \\
\hline
\end{tabular}


Table A2. Monthly and annual mean temperatures and precipitation sums for 1968-1996 for the weather stations used in this study (Swedish Meteorological and Hydrological Institute: www.smhi.se/en)

\begin{tabular}{|c|c|c|c|c|c|c|c|c|c|c|c|c|c|}
\hline & Jan & Feb & Mar & Apr & May & Jun & Jul & Aug & Sep & Oct & Nov & Dec & Year \\
\hline \multicolumn{14}{|c|}{ Mean temperature $\left({ }^{\circ} \mathrm{C}\right)$} \\
\hline Uppsala & -3.9 & -4.3 & -0.6 & 3.7 & 9.9 & 14.7 & 16.5 & 15.6 & 10.7 & 6.0 & 1.1 & -2.3 & 5.6 \\
\hline Visby & -0.7 & -1.3 & 0.5 & 4.1 & 9.5 & 14.0 & 16.6 & 16.4 & 12.1 & 7.9 & 3.9 & 1.0 & 7.0 \\
\hline Lund & -0.2 & -0.2 & 2.2 & 6.2 & 11.5 & 15.4 & 17.3 & 17.1 & 13.0 & 8.9 & 4.6 & 1.4 & 8.1 \\
\hline \multicolumn{14}{|c|}{ Mean precipitation $\left(\mathrm{mm} \mathrm{mo}^{-1}\right)$} \\
\hline Uppsala & 36 & 27 & 33 & 35 & 37 & 48 & 77 & 67 & 61 & 51 & 61 & 43 & 575 \\
\hline Visby & 50 & 32 & 37 & 32 & 30 & 36 & 54 & 54 & 60 & 57 & 62 & 54 & 558 \\
\hline Lund & 59 & 38 & 49 & 38 & 45 & 56 & 66 & 62 & 69 & 64 & 75 & 66 & 687 \\
\hline
\end{tabular}

Table A3. Parameter values, initial soil water $\left(Q_{\text {Init }}\right)$, sample size $(N)$ and coefficient of determination $\left(R^{2}\right)$ of calibration of the FOPROQ growth model (Eq. 1). $R_{\mathrm{s}}$ : relative shoot growth; $a_{\mathrm{Age}}, b_{\mathrm{Age}}$ : parameters influencing the Age function. Site subscripts refer to yield datasets (Table A1)

\begin{tabular}{|c|c|c|c|c|c|c|c|}
\hline Site & Period & $R_{\mathrm{s}}\left(\mathrm{d}^{-1}\right)$ & $a_{\text {Age }}\left(\mathrm{g} \mathrm{m}^{-2}\right)$ & $b_{\text {Age }}$ & $Q_{\text {Init }}(\mathrm{mm})$ & $\mathrm{N}$ & $\mathrm{R}^{2}(\%)$ \\
\hline Ultuna $_{4}$ & 1968-2005 & 0.22 & 400 & 1.02 & 890 & 62 & 21 \\
\hline Stenstugu $_{2}$ & 1969-2005 & 0.86 & 400 & 1.33 & 240 & 86 & 40 \\
\hline Borgeby $_{2}$ & 1961-1996 & 0.32 & 400 & 1.28 & 1800 & 40 & 32 \\
\hline Uppsala County & $1965-2008$ & 1.86 & 120 & 1.33 & 450 & 40 & 34 \\
\hline Gotland County & $1965-2006$ & 0.64 & 120 & 1.01 & 240 & 37 & 62 \\
\hline Malmöhus County ${ }^{\mathrm{a}}$ & 1965-2006 & 1.42 & 120 & 1.19 & 240 & 37 & 32 \\
\hline
\end{tabular}

Table A4. Model evaluation parameters for regressions between the climate index $X_{i}$ and time, and winter wheat yield and time, respectively. $\mathrm{R}_{2 \text { Adj }}$ : adjusted coefficient of determination (\%); $\mathrm{p}_{b X t}$ : probability value (\%) for the climate coefficient $b_{X t}=0$ (Eq. 3 ); $\mathrm{p}_{b t}$ : probability value (\%) for the time coefficient $b_{t}=0$ (Eq. 2 ). Only p values $<10 \%$ are shown. $Y_{\text {Mean }}, Y_{\text {Max }}$ and $Y_{\text {Min }}$ : mean, maximum and minimum observed yield $\left(\mathrm{kg} \mathrm{ha}^{-1} \mathrm{yr}^{-1}\right)$, respectively; $\mathrm{CV}_{Y^{\prime}}$ coefficient of variation (\%) in observed yield; $\mathrm{N}$ : sample size;

$T$ : temperature. Negative sign after a value denotes a negative relation

\begin{tabular}{|c|c|c|c|c|c|c|c|c|c|c|c|}
\hline Location & Period & $i$ in $X_{i}$ & $\mathrm{R}_{\operatorname{Adj}(\mathrm{X})}$ & $\mathrm{p}_{b X t}$ & $\mathrm{R}_{\text {Adj(Y) }}^{2}$ & $\mathrm{p}_{b t}$ & $Y_{\text {Mean }}$ & $Y_{\text {Max }}$ & $Y_{\text {Min }}$ & $\mathrm{CV}_{Y}$ & $\mathrm{~N}$ \\
\hline Ultuna $_{3}$ & 1968-1996 & $T_{\mathrm{Feb}}$ & - & - & - & - & 4793 & 6585 & 2630 & 18.4 & 25 \\
\hline Stenstugu $_{1}$ & 1969-1996 & $T_{\mathrm{Feb}}$ & - & - & 21 & 1 & 5008 & 7170 & 2420 & 23.2 & 26 \\
\hline Borgeby $_{1}$ & 1968-1996 & $T_{\mathrm{Feb}}$ & - & - & 23 & 1 & 4821 & 6485 & 2775 & 21.2 & 26 \\
\hline Säby & 1966-2002 & $T_{\mathrm{Feb}}$ & 12 & 3 & - & - & 5046 & 8410 & 3150 & 24.7 & 32 \\
\hline Ultuna $_{4}$ & 1968-1996 & GrowthModel & 24 & 1 & 21 & 1 & 5263 & 7560 & 3805 & 19.4 & 24 \\
\hline Stenstugu $_{2}$ & 1969-1996 & GrowthModel & 58 & $<1$ & 21 & 1 & 4916 & 7033 & 2423 & 22.0 & 27 \\
\hline Borgeby $_{2}$ & 1968-1996 & GrowthModel & - & - & - & - & 5258 & 6580 & 3810 & 15.4 & 18 \\
\hline \multicolumn{12}{|c|}{ 20th century } \\
\hline Ultuna $_{1}$ & $1915-1947$ & $T_{\text {Feb+March }}$ & - & - & - & - & 3930 & 5795 & 1375 & 27.7 & 33 \\
\hline Ultuna $_{2}$ & $1915-1947$ & $T_{\text {Feb+March }}$ & - & - & - & - & 3496 & 5415 & 1790 & 27.7 & 33 \\
\hline Ultuna $_{3}$ & 1968-2002 & $T_{\text {Feb+March }}$ & 25 & $<1$ & - & - & 4546 & 6585 & 2630 & 22.0 & 30 \\
\hline \multicolumn{12}{|l|}{ Region } \\
\hline Uppsala & 1965-1996 & $T_{\text {March }}$ & - & - & 29 & $<1$ & 4657 & 6300 & 2800 & 22.5 & 32 \\
\hline Gotland & 1965-1996 & $T_{\text {April }}$ & 12 & 3 & 35 & $<1$ & 4000 & 5560 & 2220 & 22.6 & 32 \\
\hline Gotland & 1965-1996 & $T_{\text {June }}$ & 11 & $4-$ & 35 & $<1$ & 4000 & 5560 & 2220 & 22.6 & 32 \\
\hline Gotland & $1965-1996$ & $T_{\text {July }}$ & - & - & 35 & $<1$ & 4000 & 5560 & 2220 & 22.6 & 32 \\
\hline Malmöhus & $1965-1996$ & $T_{\text {Nov }}$ & - & - & 62 & $<1$ & 5778 & 7860 & 4020 & 18.3 & 32 \\
\hline Malmöhus & $1965-1996$ & $T_{\text {Jan }}$ & - & - & 62 & $<1$ & 5778 & 7860 & 4020 & 18.3 & 32 \\
\hline Malmöhus & 1965-1996 & $T_{\text {April }}$ & 23 & $<1$ & 62 & $<1$ & 5778 & 7860 & 4020 & 18.3 & 32 \\
\hline Malmöhus & 1965-1996 & $T_{\text {Aug }}$ & - & - & 62 & $<1$ & 5778 & 7860 & 4020 & 18.3 & 32 \\
\hline Uppsala & $1965-1996$ & GrowthModel & 29 & $<1$ & 37 & $<1$ & 4816 & 6300 & 2820 & 17.8 & 29 \\
\hline Gotland & $1965-1996$ & GrowthModel & 37 & $<1$ & 35 & $<1$ & 4000 & 5560 & 2220 & 22.6 & 32 \\
\hline Malmöhus & 1965-1996 & GrowthModel & 12 & 3 & 62 & $<1$ & 5778 & 7860 & 4020 & 18.3 & 32 \\
\hline
\end{tabular}

